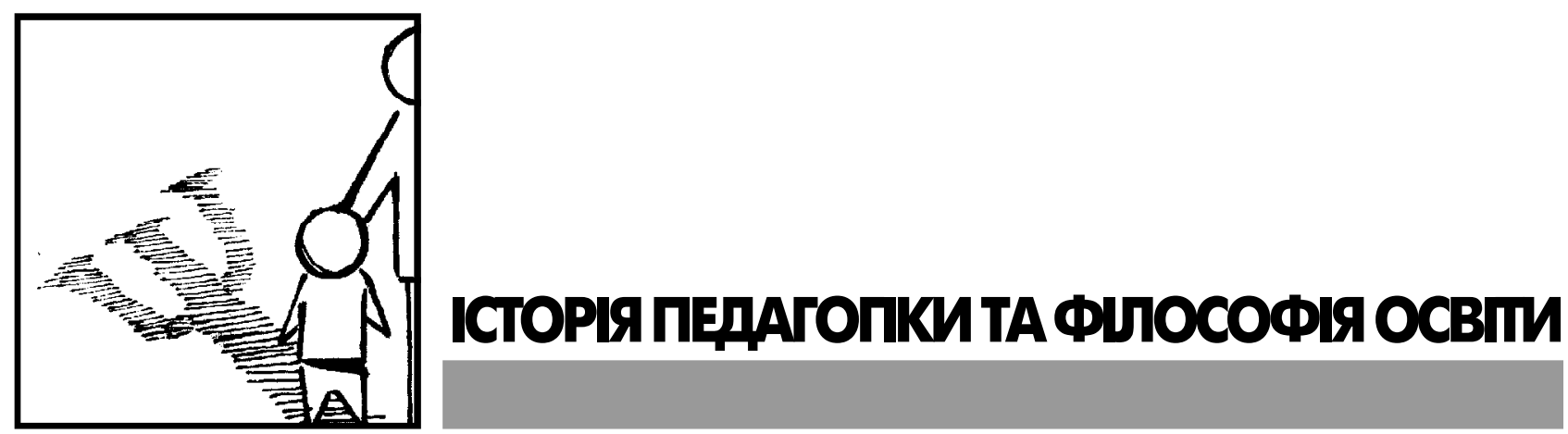

УДК: 378. 147. 091. 32: 17216

ГРИГОРІЙ ВАСЯНОВИЧ, доктор педагогічних наук, професор, професор кафедри гуманітарних дисииплін та соиіальної роботи, Львівський державнии університет безпеки життєдіяльності, Україна

ORCID. org/0000-0002-2346-193x

wasianowych@ukr.net

\title{
КУЛЬТУРНО-ГУМАНІТАРНІ ЗАСАДИ ОСВІТНЬОГО ПРОЦЕСУ І СУЧАСНА РЕАЛЬНІСТЬ
}

\author{
Hryhoriy Vasyanovych, Doctor of Pedagogical Sciences, Professor, \\ Professor of the Department of Humanities and Social Work, \\ Lviv State University of Life Safety, Ukraine
}

\section{CULTURAL AND HUMANITARIAN FUNDAMENTALS OF THE EDUCATIONAL PROCESS AND MODERN REALITY}

\begin{abstract}
У статті аналізуються питання сутності і змісту сучасного навчального процесу, у якому головне місце посідають культурно-гуманітарні засади його організації. З'ясовується сугнісна відмінність між традиційним та інноваційним підходами щодо реальних можливостей продуктивного функціонування освітнього процесу 3 метою підготовки фахівців не лише 3 погляду їх професійної компетентності, а й у контексті їх духовності. Обгрунтовується необхідність творчого застосування принципів природовідповідності й культуровідповідності в освітньому процесі. Доводиться ідея діалектичної єдності культури, науки і освіти на сучасному етапі їх реформування.
\end{abstract}

Ключові слова: освітній процес, культура, культуровідповідність, освіта, особистість, учитель, гуманізм.

Summary. The article analyzes the issues concerning the essence and content of the modern educational process, in which the cultural and

(c) Г. Васянович humanitarian foundations of its organization take the main place. The author reveals essential difference between traditional and innovative approaches to the real possibilities of productive functioning of the educational process in order to train specialists not only in terms of their professional competence, but also in the context of their spirituality. The article substantiates the necessity of creative application of the principles of nature congruity and cultural conformity in the educational process. The author proves the idea of the dialectical unity of culture, science and education at the present stage of their reformation. The main shortcomings of the educational process concerning the formation of general culture in future specialists are highlighted. Specific ways of its improvement are suggested.

Key words: educational process, culture, cultural conformity, education, personality, teacher, humanism.

Мета: проаналізувати сучасний стан навчального процесу в його культурно-гуманітарному контексті.
Постановка проблеми в загальному вигляді. Якісна підготовка фахівця будь-якого профілю вимагає добре налагодженого навчального процесу, що вибудовується на притаманних йому законах і закономірностях, дидактичних принципах, технологіях, а звідси - передбачає органічну єдність викладання й учіння. Він визначається навчальними планами, програмами і включає всі види навчальних занять. У кожному закладі освіти навчальний процес має свої особливості й організовується відповідно до його типу і профілю, а також до форми й системи навчання. Усталеною думкою провідних учених стосовно навчального процесу є та, що він тісно взаємопов'язаний 3 процесом виховання (Гончаренко, 1997, с. 223). Нормативною основою, яка визначає організацію навчального процесу, є Закон України "Про освіту", прийнятий у вересні 2017 року. Натомість варто зазначити, що навіть найкращий документ не може врахувати всіх нюансів, пов'язаних 3 навчальним процесом, оскільки він перебуває у постійному динамічному розвиткові, змінах, pe- 
формуванні тощо. Усе це з очевидністю вказує на те, що переміни в навчальному процесі відбуваються у гострій боротьбі традиційного та інноваційного підходів до його організації.

Традиційний підхід усе ще тяжіє до жорсткого адміністрування, застосування старих методів, форм навчання, тоді як інноваційний вимагає послідовного впровадження нових навчальних технологій, утвердження демократичних форм суб'єкт-суб'єктних взаємин на всіх рівнях його реалізації. Неприхованим, і як таким, що гальмує можливості вдосконалення навчального процесу, є факт його технократизації і недооцінка ролі культурно-гуманітарних засад у системі реформування освіти України взагалі. Розглянемо цю проблему детальніше.

Аналіз досліджень і публікацій. Окреслена проблема досліджується як вітчизняними, так і зарубіжними вченими. Зокрема, культурологічний аспект навчального процесу і освіти вивчали: В. Андрущенко, М. Бахтін, В. Біблер, І. Зязюн, В. Кудін, О. Лосєв, О. Отич, О. Рудницька, Г. Філіпчук та інші. Питанням гуманізації та гуманітаризації освіти присвятили свої праці: Ш. Амонашвілі, Г. Балл, І. Бех, М. Берулава, Г. Васянович, С. Гончаренко, В. Кремень, В. Жуковський, О.Романовський та інші. Значний внесок у розвиток й удосконалення навчального процесу на засадах його інформатизації здійснили: В. Биков, А. Гуржій, Р. Гуревич, М. Кадемія, Г.Кедрович, М. Козяр, А. Литвин та інші.

Виклад основного матеріалу дослідження.

Культурологічний аспект навчального процесу.

Ідея побудови навчального процесу на засадах культури має давню традицію. Уже Аристотель доводив, що культура - це єдність ідеального і матеріального. Як система програм людської діяльності, вона безпосередньо впливає на розвиток освіти. У свою чергу, освіта - це можливість самоздійснення, самореалізації особистості (Аристотель).

Пізніше, починаючи з XVIII ст., німецькі філософи, педагоги й організатори освіти послідовно обгрунтовували й утверджували ідею єдності культури і освіти (Г. Гадамер, Г. Гегель, И. Гербарт, Й. Гердер, В. Гумбольдт, А. Дістервег, І. Кант, Й. Фіхте та ін.). Зокрема, I. Кант у відомій праці
"Критика здатності судження" писав, що прикінцевою метою природи стосовно людського роду є не стільки щастя, скільки духовна культура людини. Філософ дотримувався тієї позиції, що за інших умов було б незрозумілим, для чого людині Бог дав розум і свободу. Сутність культури, на думку мислителя, полягає в тому, що людина набуває здатності ставити будь-які цілі і досягати їх. "Набуття... розумною істотою здатності ставити будь-які цілі взагалі (отже, у її свободі) - це культура" (Кант, 1966, с. 464). У культурі, на думку І. Канта, якби перехрещуються дві лінії людського розвитку: необхідність фізичної досконалості, яка і $є$ "культурою всіх взагалі здатностей для сприяння поставленій розумом мети" (Кант, с. 326) і необхідність моральної досконалості, "культури моральності в нас", яка полягає в тому, щоб "свій моральний обов'язок, і притому із почуття обов'язку (щоб закон був не лише правилом, а й мотивом вчинків" (Кант, с. 327).

А. Дістервег, якого за життя називали "учителем учителів", обгрунтував та активно впроваджував у навчальний процес принцип культуровідповідності. 3 цього приводу він писав, що, крім головного принципу - природовідповідності, існує ще інший: "Це принцип культуровідповідності, права якого неможливо заперечувати, хоч він і не може претендувати на таку ж загальність, як принцип природовідповідності" (Дистервег, 1956, с. 228). Педагог доводив, що розумне, творче застосування принципу культуровідповідності має відповідати вимогам культури тієї спільноти, народу, середовища і часу, у яких відбувається навчальний процес. Отже, особистість має формуватися на засадах національно специфічній, соціально, культурно орієнтованій матриці народу, що проживає на певній території і нерозривно пов'язаної з історією, наукою, традиційно-побутовою культурою. Саме за цих умов особистість здатна долучатися до загальнолюдської культури як універсальної системи адаптації й соціалізації у певному часовому вимірі. Отже, є всі підстави говорити про те, що принцип культуровідповідності має пронизувати всю педагогічну діяльність, входити потужною складовою у зміст навчального процесу, технологію навчання і виховання. Цю думку постійно і послідовно відстоює академік
Г. Філіпчук, котрий пише: ". . .зважаючи на полікультурність і потребу національної самоідентичності, відмінності у традиціях, стилі життя і взаємозв'язках, на рівні етносів провідною тенденцією у філософії ставатиме розвиток національного характеру, способу мислення, власного розуміння вітчизняної і світової культури та історії, національного егоцентризму, а з іншого боку - закономірним є формування планетарного бачення на основі зростання контактів, взаємозв'язків між націями, що забезпечуватиме гармонійний розвиток особистісного, національного й загальнолюдського. Таке розуміння діалектики освіти як діалектики особистісного, етнічного і загальнолюдського $є$ найважливішою засадничою умовою для істини суспільного прогресу" (Філіпчук, 2013, c. 204-205).

Утім, зазначимо, що такі теоретичні положення не завжди знаходять реалізацію на практиці. Проведений контент-аналіз робочих і навчальних програм Дрогобицького державного педагогічного університету імені Івана Франка та Львівського державного університету безпеки життєдіяльності засвідчив, що навіть у змісті курсів із соціально-гуманітарних дисциплін питання загальної культури представлені не на належному рівні. Головними недоліками даних програм є те, що в них простежується:

а) відсутність чітко сформульованих мети і завдань $з$ проблем формування у курсантів і студентів основ національної культури;

б) недостатня підготовка викладацького та керівного складу 3 питань загальної і моральної культури;

в) відчутним є слабке науковометодичне забезпечення 3 питань сутності і змісту української культури;

г) фрагментарне використання інформаційно-комунікаційних технологій у навчальному процесі з метою формування вітчизняної і загальнолюдської культур;

д) недостатнє володіння професорсько-викладацьким складом закладу методом "діалогу культур";

е) несформованість системи лідерства у викладацькому і студентському середовищі стосовно опанування культурно-гуманітарних цінностей, які виробили людство і нація.

Принагідно зазначимо, що культурологічний підхід до організації 
навчального процесу добре простежується у працях і практичній діяльності таких українських педагогів, культурно-освітніх діячів, як: Г. Ващенко, Б. Грінченко, М. Грушевський, М. Драгоманов, О. Духнович, I. Зязюн, І. Огієнко, С. Сірополко, Г.Сковорода, К. Ушинський, I. Франко, П. Юркевич, Я. Ярема та інших. Вони доводили, що культура, крім інших, має ту особливість, що вона завжди спрямована на духовний розвиток особистості. Ось чому так важливо, щоб весь навчальний процес був змістовно наповнений кращими зразками вітчизняної і світової культури. Культура й освіта виконають свою місію тоді, коли вони оновлюватимуть людський дух і душу, підноситимуть людину до висот пізнання й самовдосконалення. Як справедливо писав академік I. Зязюн: "Головне в людині - пї духовність на засадах національної культури. Йдеться про найважливіше в ній, що в історичному аспекті є вічним і непорушним. Адже в кожного народу $є$ віками відшліфовані культурні цінності, здобутки, що формують неповторність, оригінальність і велич національного духу людини... Найвагомішим виміром національної неповторності людини є народна культура як основа її духовності" (Зязюн, 2000, с. 304). Учений вважав, що вища і середня школа мають подолати різноманітність освітніх програм і навчальних планів. Освітні програми і навчальні плани повинні консолідуватися на культурологічному, інтеграційному рівнях, що сприятиме підвищенню продуктивності навчального процесу загалом. Це потрібно робити ще й тому, що здобутки народної, як і світової культури, ще не ввійшли у свідомість багатьох молодих людей. Практика засвідчує засміченість їхньої свідомості "ерзацами культури", різного роду "страшилками", продукцією "маскульту" тощо. Значна кількість студентської молоді не відвідує театр, картинні галереї, музеї, що вкрай негативно позначається на їх духовно-душевному світі, смислах, життєвих цінностях і вчинках. Нашестя духовного примітивізму має хоча б частково долатися під час добре організованого навчального процесу, побудованого на культурологічних засадах.

Гуманітарний аспект навчального процесу.

Культурологічна складова навчального процесу тісно пов'язана 3 гуманітарною, більше того, вони доповнюють одна одну, а завдяки цьому навчання і виховання підростаючого покоління стає продуктивним.

Натомість можна говорити і про те, що педагогічний процес взагалі $€$ гуманітарним феноменом, оскільки, маючи людську природу, він задає тонус духовній культурі. Гуманітарна парадигма орієнтована на становлення і розвиток особистості в лоні культури, на пізнання і розкриття сутнісного в ній. Ця парадигма є прямо протилежною тій, що отримала назву "наповнювальної" (відомий давній вислів про те, що людину можна наповнити знаннями, як наповнюють якусь посудину). Г. Сковорода, заперечуючи таку думку, писав: "Серце тоді насичується, коли освічується" (Сковорода, 1983, с. 174). Мислитель мав на увазі, передусім, освітити, "запалити" розум дитини, спонукати іiі до мислення, "чуттєвосердечного" сприйняття світу. А сучасний відомий педагог-гуманіст Ш. Амонашвілі $з$ приводу того, що головним під час навчального процесу є формальне наповнення голови учня певною сумою знань, висловився радикально: "Діти не можуть бути міхами для програми"! Педагог доводить, що навчальний процес має бути одухотворений красою спілкування, гуманним, душевним ставленням учителя до дитини. Він наголошує: "Коли я на уроці- зі мною Бог і діти"! (Амонашвили, 1991).

Навчальний процес у гуманітарному аспекті дозволяє людині стати учасником культурного процесу, отже, не стільки задовольняти свої потреби, інтереси, скільки бути носієм, творцем культури. I хоча це виглядає дещо парадоксально, але саме тут починаються проблеми. Педагогічна практика свідчить, що не лише кожний учень/студент є готовим до такої творчості, а часто-густо й сам педагог. Однією з причин такої ситуації $є$ предметоцентризм. Це означає, що деякі вчені та педагогипрактики пропонують здійснювати гуманітаризацію і гуманізацію навчального процесу екстенсивним методом, тобто нарощуючи в навчальних планах кількість гуманітарних предметів. Про те, що цей шлях $\epsilon$ малопродуктивним, сьогодні вже стало очевидністю. Тому, на наш погляд, орієнтуватися у даному питанні варто на інтенсивний метод, який дозволяє радикально оновлювати не лише той чи інший предмет, а й на- вчальний процес у цілому. Тут на допомогу приходять і стиль спілкування у системі "учитель - учень; викладач - студент", і позитивний вплив на суб'єкта навчання організованого гуманного освітнього середовища. На нашу думку, таке середовище активно формує людські цінності і життєві смисли (Васянович, 2015; Руднииька, 2005).

Хочеться звернути увагу й на такий аспект проблеми. Те, що нині можна характеризувати як досягнення тієї чи іншої науки, не завжди потрапляє в поле зору не лише учнів/ студентів, а й учителів, викладачів вишів; це означає, що суб'єкти навчального процесу часто-густо "споживають" лише фрагменти науки, культури. I, навпаки, іноді допитливий учень/студент здатний отримувати такий комплекс нових знань 3 питань культури, які недосяжні його учителям (особливо тим, які за якихось причин слабко володіють інформаційно-комунікаційними технологіями). Це може викликати досить серйозні непорозуміння між суб'єктами навчального процесу, нівелювати певною мірою роль педагога.

Крім того, сьогодні надто важливим для педагога $є$ питання пізнання феномена молодіжної (студентської) субкультури, вивчення не лише позитивного, а й негативного досвіду учнів/студентів. Вважаємо це особливо важливим $з$ огляду зростаючої в суспільстві десоціалізації й дегуманізації, вияву з боку молоді агресії, бездуховності, наркозалежності тощо. I тут на допомогу педагогам мають прийти нетрадиційні форми занять, можливо навіть такі, що певною мірою суперечать усталеним у класичній педагогіці. Такий досвід репрезентують кращі заклади освіти України (Київський національний університет імені Тараса Шевченка, Національний університет імені Михайла Драгоманова, Вінницький педагогічний університет імені Михайла Коцюбинського та ін.).

Гуманітарний аспект навчального процесу орієнтує учителів, викладачів на те, щоби вони більш уважно ставилися до етнічної неоднорідності вихованців. Ця проблема для нас останнім часом зросла у зв'язку з подіями на Сході країни, міграцією, експансією деяких наших сусідніх держав тощо. Безумовно, що в такому сенсі все більш вартісним у навчальному процесі постає метод діалогу 
культур, який відкриває нові можливості взаємопізнання і взаєморозуміння.

Аналізуючи сучасний навчальний процес $з$ погляду гуманістики, доречним, на наш погляд, звернути увагу і на таку проблему. Вважаємо, що останнім часом ми занадто захопилися європоцентризмом і нескінченним (іноді зовсім безглуздим) реформуванням освіти, отже, і такою центральною ланкою, як навчальний процес. Часто-густо копіюється "західний варіант", який уже давно відкинутий в освітніх системах розвинених країн. Таке "мавпування" (Сковорода) чужого досвіду нічого доброго не приносить, навпаки, дезорієнтує педагога, перетворює його в "бухгалтера" в гіршому вигляді, обмежує його свободу, дії та негативно позначається на фізичному й душевно-духовному здоров'ї. Перебування у стані якогось невідомого очікування (що там ще придумають чиновники від освіти?), постійні перевантаження педагога і учня призводять до зривів: в учителів - до небажання якісно навчати, а в учнів - до небажання сумлінно навчатися. Щоби бути правильно зрозумілим, наголосимо: ми не проти реформування, навпаки, ми за реформування освіти, але реформування розумного, продуктивного, такого, що відповідає стратегії розвитку особистості і суспільства. Реформування освіти не може зводитися до олівця або парти, головне не забувати таких чітких і зрозумілих формул геніального Івана Франка: "Учителем школа стоїть!", а ще: "Гуманним будь, і хай твоя гуманність пливе 3 криниці чистої любові"!

Хочемо звернути увагу і на такий аспект проблеми, як культура і компетентність тих, хто планує й організує навчальний процес. Думаю, що висловлю не лише свою власну думку $з$ цього важливого питання. На жаль, до планування навчальних занять часто приходять випадкові люди, котрим зовсім однаково, як буде складений розклад, чи у відповідній аудиторії і таке інше. Як можна говорити про компетентність, наприклад, співробітників того чи іншого навчального відділу, якщо протягом лише двох місяців навчального процесу розклад змінюється 5-6 разів! Це дезорієнтує не лише викладачів, а і студентів, породжує серйозні непорозуміння між суб'єктами освітнього процесу тощо.
Висновки та перспективи подальших досліджень. Отже, на основі викладеного можна зробити такі висновки:

1. Культурно-гуманітарні засади мають визначати сутність і зміст сучасного навчального процесу в освітній системі України.

2. Технологічні явища, які все більше входять у серцевину навчального процесу, не повинні зводити його до технократизму. Природа навчального процесу не лише має залишатися культурно-гуманітарною, а й набувати нових обрисів і значень відповідно до нагальних потреб розвитку особистості і суспільства.

3. Навчальний процес-це завжди і передусім особистісне ставлення людей до Істини, Добра і Краси, які разом сповідують, утверджують духовні цінності і смисли буття. Він має бути адекватним власній природі, отож, відповідати складному, багатовимірному суб'єктивному світові людини.

До подальших питань дослідження відносимо: методологію наукового аналізу сучасного навчального процесу; досвід управління навчальним процесом у зарубіжних країнах світу; проблему лідерства в організації навчального процесу тощо.

\section{СПИСОК ЛІТЕРАТУРИ}

Амонашвили, Ш. (1991). Как живете дети? Кн. для учителя (2-е изд.). Москва : Просвещение.

Аристотель. (1983). Политика. Собр. соч. : в 4 т. Москва : Мысль.

Васянович, Г. П. (2015). Гуманітарна освіта у процесі підготовки кваліфікованого робітника. 3б. наук. праць. Т. 5. Львів : Норма.

Гончаренко, С. У. (1997). Український педагогічний словник. Київ : Либідь.

Дистервег, А. (1956). Избранные педагогические сочинения. Москва: Гос.- уч.-педгиз.

Зязюн, І. А. (2000). Педагогіка добра: ідеали і реалії : наук.-метод. посіб. Київ : МАУП.

Кант, И. (1966). Критика способности суждения. Сочинения в $6 \mathrm{~m}$. Т. 5. Москва : Мысль.

Кант, И. 1966. Метафизика нравов. Метафизические начала учения о добродетели. Сочинения в $6 \mathrm{~m}$. Т. 4. Ч. 2. Москва : Мысль.

Рудницька, О. П. (2005). Педагогіка загальна та мистецька. Тернопіль : Навчальна книга-Богдан.
Сковорода, Г. С. (1983). Сад пісень. Вибр. тв. Київ : Веселка.

Філіпчук, Г. Г. (2013). Національна освіта: особистість і суспільство. Збірник наукових працъь. Чернівці : Зелена Буковина. 